\title{
WHY DOES THE RECENTLY ADOPTED PERFORMANCE MEASUREMENT SYSTEM IN INDONESIAN LOCAL GOVERNMENT NOT WORK WELL?
}

\author{
HERU FAHLEVI' (hfahlevi@unsyiah.ac.id) \\ DHARNI NUZULLA ${ }^{1,2}$ \\ HASAN BASRI ${ }^{1}$
}

${ }^{1}$ Accounting Department, Economics and Business Faculty, Universitas Syiah Kuala, Banda Aceh Indonesia

${ }^{2}$ Ar-Raniry State Islamic University, Banda Aceh, Indonesia

\begin{abstract}
A B S T R A C T
The purpose of this study is to gain insight on the implementation of a newly adopted Performance Measurement System (PMS) in Sabang local government - Indonesia. It is a case study based qualitative research which was carried out at the local government of Sabang. Data were collected through document analysis, questionnaires, and followed by semi-structure interviews. The questionnaires were distributed to key officers of 7 working unit/departments (or Satuan Kerja Perangkat Daerah) out of 31 departments in total within the city of Sabang. The interviewees are head of the departments, the secretary, head of program and reporting division of each working unit. The data were analyzed by using qualitative data analysis technique. The institutional theory was used as a basis for analyzing and discussing the results obtained. This study uncovers that the PMS concept and functions have not fully understood by most of the key officers. Consequently, the recently developed PMS is not utilized optimally and thus it does not contribute to a better performance management system of the local government. The reasons why it is now work well are incapacity of the human resource, unclear job description, lack of organizational commitment and the absence of the performance evaluation. Thus, it can be concluded that pre-requirements and pre-condition need to be fulfilled before adopting a new PMS, especially where the PMS is not initiated by the organization itself, rather imposed by the central government or other organization.
\end{abstract}

Keywords: Performance measurement, performance indicators, SAKIP, Indonesia,

Tujuan dari penelitian ini adalah untuk mendapatkan pemahaman yang mendalam mengenai implementasi Sistem Pengukuran Kinerja (SPK) yang baru diadopsi di pemerintah daerah Kota Sabang - Indonesia. Penelitian ini adalah penelitian kualitatif yang menggunakan desain studi kasus padai pemerintah daerah Kota Sabang. Data dikumpulkan melalui analisis dokumen, kuesioner, dan diikuti oleh wawancara semi-struktur. Kuesioner dibagikan kepada staf senior dari 7 unit / departemen kerja (Organisasi Perangkat Daerah/OPD) dari total 31 OPD di kota Sabang. Narasumber yang diwawancarai adalah kepala OPD, sekretaris, kepala program dan divisi pelaporan dari masing-masing unit kerja. Data dianalisis dengan menggunakan teknik analisis data kualitatif. Teori institusional digunakan sebagai dasar untuk menganalisis dan mendiskusikan hasil yang diperoleh. Studi ini menemukan bahwa konsep dan fungsi SPK belum sepenuhnya dipahami oleh sebagian besar narasumber. Akibatnya, SPK yang baru dikembangkan tidak dimanfaatkan secara optimal dan sehingga tidak berkontribusi pada sistem manajemen kinerja yang lebih baik di pemerintah daerah yang diteliti. Sejumlah penyebab yang ditemukan adalah kurangnya kapasitas sumber daya manusia, deskripsi pekerjaan yang tidak jelas, kurangnya komitmen organisasi dan kurang optimalnya sistem evaluasi kinerja. Dengan demikian, dapat disimpulkan bahwa sejumlah prasyarat dan kondisi harus dipenuhi sebelum mengadopsi sebuah SPK baru, terutama di mana SPK tidak dikembangkan sendiri, melainkan diperintahkan oleh pemerintah pusat atau organisasi lainnya

Kata kunci: Pengukuran Kinerja, Indikator Kinerja, SAKIP, Indonesia, Pemerintah Daerah

\section{INTRODUCTION}

Since the 1970s there have been serial and substantial reforms of public sector man- agement around the globe. The reforms are mostly associated with the term of New Public Management (hereafter NPM). Under 
the flag of NPM, government performance measurement approach has been changed from an input-oriented approach to a more output and outcome approach. Previously, the traditional performance evaluation relied heavily on budget variance (Jansen, 2008). The NPM reforms have introduced a more business-like method for example balance scorecard, benchmarking and total quality management.

The adoption of a new performance measurement system (PMS) has been the agenda of public sector reforms to ensure the achievement of government ultimate objective rather than merely on financial indicators (Verbeeten, 2008). However, the implementation of such new perspective of PMS is challenging and problematic and even created unintended outcomes (Arnaboldi, Lapsley, \& Steccolini, 2015). In fact, these challenges and impediments have attracted many studied in the last few years (see for example Fryer, Antony, Ogsden, \& Fryer, 2009, Arnaboldi et al., 2015)

The introduction of a more outcomeoriented performance measurement in government institution is a worldwide phenomenon including in Indonesia. Indonesia has started to improve the government performance measurement mechanism along with the ideas of bureaucratic reform and good governance (Jurnali \& Siti-Nabiha, 2015; Akbar, Pilcher, \& Perrin, 2012). The assessment and measurement of government institution performance in Indonesia have been reformed since the enactment of Presidential Instruction No.7 of 1999 on Performance Accountability of Government Institution (or Akuntabilitas Kinerja Instansi Pemerintahan/ AKIP) in which the Government Institution Accountability System (or Sistem Akuntabiltas Instansi Pemerintahan/ SAKIP) and Government Performance Accountability Report (Laporan Akuntabilitas Kinerja Instansi Pemerintahan/ LAKIP) become inseparable and crucial parts (Akbar, Pilcher, \& Perrin, 2012; Akbar et al., 2015).

Despite a long implementation process, the application of the new PMS in Indonesia has not run optimally. Previous studies found that the implementation of PMS in Indonesian local governments is still far from expectation. Akbar et al. (2012) studied the implementation of PMSs (LAKIP) in Indonesian local government (ILG). The respondents of this study are both low-level officers and top managers of ILGs. They found that the performance indicators were developed and adopted mainly to fullfil regulatory requirements, instead of improving the efficiency and effectiveness of their organizations.

This study aims to explore how an Indonesian local government adopts and uses the recently developed PMS to improve its performance. It assesses the working unit officers' understanding on PMS, its implementation and how the recently adopted PMS used to measure and evaluate performance. This study is undertaken in Sabang, one of the local governments in Aceh province. The local government of Sabang has been selected as the case in this study because it is not a new established local government and the accessibility of data.

Moreover, the financial report of local government of Sabang has been audited and obtained an unqualified opinion from the Indonesian government auditor board since 2009. However, the government seems to fail to achieve a similar performance in term of accountability as its accountability reports obtained C criteria (poor) between 2014 until 2016. This assessment is conducted by the ministry of internal affairs in which PMS is the main indicator.

Besides, Aceh government is under public scrutiny due to its failure to increase performance indicators although it has received a significant increase of money from the central government (Fahlevi, Muhardiansyah, \& Aliamin, 2018). It is a paradox as the Aceh government has obtained more money with regard to the Special Autonomy Fund (or Dana Otonomi Khusus) which is not followed by the improvement of community welfare, especially the reduction of the poverty rate.

Unlike previous studies on Indonesian PMS, this study adopted a case study research design. Thus, a more detailed information and understanding in how the PMS is adopted and its role in performance 
management can be fully depicted.

This paper is classified into 5 sessions. The second session provides a theoretical framework, a review of previous studies and description of Indonesia government as well as its performance management system. The research design and method are presented in the third session. Later on, the result of this study and its discussion are exhibited in the fourth session. The last session is conclusion and recommendation for further studies.

\section{LITERATURE REVIEW AND HYPOTHESIS DEVELPOMENT}

\section{Performance measurement in public sec- tor organizations}

It is widely accepted that the NPM reform movement is the main trigger and driving force of the PMS development in public sector (see for example Moynihan, 2006, in the US context, and Akbar et al., 2012 in Indonesian context). By definition, performance measurement is a self-evaluation which is directed at the organizational action and output monitoring, analyzing, explaining and comparing it with other organizations (Kuhlmann, 2010). A performance measurement is expected to provide data on how efficient and effective a public service is provided to the community (Greiling, 2006).

The performance measurement and performance management system are closely related. A PMS is required to ensure that performance measurement implementation has a directed implementation concept. A performance management requires a reliable PMS as a key to successful organization. A PMS is designed to monitor the implementation of organization's plans and to determine the indicators of successful and unsuccessful plans and how to fix them. A PMS can be used to measure and report on performance and to understand how performance process affects the organizational learning (Atkinson and McCrindell, 1997).

A reliable PMS should include several important components. Jurnali \& SitiNabiha (2015) mentioned that there are five things that must be included in PMS to achieve good results. First, the goals and target of organization and mechanisms to measure and monitor the achievement of the objectives; Second, the strategies or processes used to implement and measure the achievement; Third, determination of performance targets and measurement of effectiveness and efficiency; Fourth, punishment and reward system as consequences of achievement or failure to attain the performance targets; and Fifth, the information flow which enables organizations to learn from experiences. In other words, PMS as an outline has four aspects to be fulfilled namely what will be measured (performance indicators); when and how to measure (performance measurement); the interpretation of measurement (analysis); and Fourth, communicating the measurement results in performance evaluation and decision making (Fryer et al., 2009). The performance information that has been obtained from the interpretation of performance measurement should be used in the process of evaluation and decisionmaking.

The design and implementation process of PMS in private sector is rather clear and straightforward compared to the PMS implementation in public sector (Rantanen, Kulmala, Lönnqvist, \& Kujansivu, 2007). The public sector organizations are more complex because they are intervened by political interest of its stakeholders (Arnaboldi et al., 2015). The public sector so unique that it is almost impossible to have a single solution for all public sector organizations that are partially or fully different from one another in term of their economic performance, political philosophy, the involvement of stakeholders and demand for public services (CIMA 2011 as cited in Arnaboldi et al., 2015).

Rantanen et al. (2007) identify the specific problems faced by the Finnish public sector organizations in designing and implementing performance measurement systems (PMS). This study is a multiple case study that conducted in a Finnish university, a state agency working under the Ministry of Trade and Industry, the maintenance function of the Finnish Defense Forces (FDF). They documented four main causes for the problems of performance measure- 
Why does the recently adopted performance measurement system in Indonesia local government not work well? (Fahlevi, Nuzulia, dan Basri)

ment in Finnish public organizations. First, the public sector has many stakeholders who are different needs. Thus, their needs could be conflicted one another. Second, it is difficult to define the end products and goals of the public sector as the organizational structure are multifaceted and a clear chain of command does not existed (Rantanen et al., 2007). Third, property ownership in public sector is lacking because everything is used or owned collectively. Fourth, the management skills of public managers are not sufficient as it is required. This happens because the selection procedures of managers in public sectors do not seek the best manager, but the most senior ones. As a result, they do not know what to measure and how to measure.

\section{Institutional theory}

Institutional theory has been used widely to understand the motivation and reasons behind accounting changes in the public sector organization (see for example Fahlevi, 2016). The theory assumes that any implementation of the new method in an organization reflects the desire to improve performance and achieve its goals. However, this is not always the case. Several studies have approved other motivation behind changes, namely to attain legitimization from outsiders particularly the key stakeholders.

The implementation of performance management system is local governmental institutions is prone to legitimization or obedience seeking (Brignall \& Modell, 2000). The reason could be that the local governments substantially depend on the central government fund transfer, and in exchange, controlled by the central government. In fact, many changes in local governments' system are mostly injected from the central government. Several previous studies have confirmed this theory.

In decentralized governance like Indonesia, the central authority usually has greater coercive power than other constituencies over the local Governments. Related to the implementation of PMS in LGs in Indonesia, it is found that the isomorphism mechanism occurs in Local Government is a coercive and normative mechanism. The apparatus of LG in implementing PMS only have the characteristic of conformance, not performance. The Local Government tends to implement it only for reasons of obligation from the Central Government. On the other hand, managers in LGs normatively implement PMS because of the additional technical knowledge they would gain through employee training (Akbar et al., 2012).

According to (Ashworth, Boyne, \& Delbridge, 2009), institutional theorists believe that organizations seek for legitimacy by conforming to the so-called isomorphic pressures in their environment. Thus, the motivation behind any adoption of new method or techniques can be associated with the organization's effort to conform to the expectations of the main stakeholders, rather than to achieve a better performance. Moreover, there are types of the institutional isomorphism introduced by DiMaggio \& Powell (1983) , namely mimetic, coercive, and normative Mimetic isomorphism is reflected by the intention of the organization to imitate other organizations' method to reduce the possibility of failure (Ahyaruddin \& Akbar,2018). Meanwhile, the coercive isomorphism is related with external pressure to adopt the certain method. This external pressures can be originated from financers, donators or governments (Ashworth et al 2009). Lastly, the normative isomorphism can be associated with norms or standards proposed by professional communities to the organizations (Arnaboldi \& Azzone, 2010). These three pressures or isomorphism have been widely used to understand changes in public sector organizations, including the adoption of PMS.

\section{PMS in Indonesian local governments}

The 1998 Indonesia's reform can be said as the trigger of administrative and governmental changes in Indonesian afterward. The new government has initiated several significant changes including decentralization and the creation of a good governance. The central government has played a dominant role in the reform agenda including in the application of PMS in Indonesian local 
governments.

After 1998, Indonesian local governments have gained more power and autonomy. The local governments comprise of two levels, namely provinces and districts/ cities. According to Law 22/1999 revised by Law 32/2004 and Law 25/1999 revised by Law 33/2004, the central government delivered the mandate to provincial government to act as a coordinator for a number of districts/cities as well as the representative of the central government. Meanwhile, core public services are managed by each district/ city (Jurnali \& Siti-Nabiha, 2015)

Since 1999, all government agencies and local governments are required to develop performance accountability system (SAKIP) and prepare performance accountability report (LAKIP). The objective is to improve the effectiveness, efficiency, and accountability of each government level (Jurnali \& Siti-Nabiha, 2015). For the first time, the local governments need to analysis the input and outcome of their program/spending rather than focus solely on budget realization. The new system asks for strategic planning, performance planning, and performance measurement every year and evaluates these planning with the intended output of each local government. In the preparation of LAKIP, it is required that local government and government agencies formulate a well-defined planning, performance target, indicators of measurement, system of the data collection and strategies to achieve them. The LAKIP will be sent to and evaluated by the Ministry of State Apparatus and Bureaucracy Reform (MSABR).

The ultimate goal of the newly developed PMS is actually to improve the performance of local government and agencies. The LAKIP and its developed indicators should be used to evaluate the program and to develop the budget. However, previous studies found unintended results. Jurnali \& Siti-Nabiha (2015) reviewed the regulations and guidelines related to Indonesian PMS and found a comprehensive regulation on PMS, except on the punishment and reward system.

Moreover, other studies demonstrated that PMS is adopted only for aligning with the formal request of the central government order. Akbar et al (2012) studied the implementation of SAKIP in Indonesian local governments. They found that the developed performance indicators are used mostly to fulfill the regulatory requirements, not to make their organization more effective and efficient. More recently, Ahyaruddin \& Akbar (2018) in their study on the implementation of LAKIP in Yogyakarta Province found a similar result. The study unveils the presence of coercive, mimetic and normative pressures in the implementation of the PMS/ SAKIP. Consequently, the indicators within the LAKIP is ignored when the government makes a decision and plan the strategies (Ahyaruddin \& Akbar, 2018).

\section{RESEARCH METHODS}

This study is a qualitative research using case study approach of which the data were obtained by data triangulation through questionnaires, semi-structured interviews, and document analysis. The case study was selected since it is able to focus on a particular unit with various phenomena and is more appropriate to examine problems that require in-depth understanding of issue of public policy implementation (Bungin, 2007).

There are two sets of questionnaires in this study, namely questionnaire with a choice of answer and open questions which offer freedom to respondents to provide answers based on the realities. The questions with a choice of the answer had 2 (two) optional answers namely, agree (marked 1) and disagree (marked 2). The choice of answers of each question had a different weight which depended on the context of the question. The purpose is to assess the understanding of respondents on PMS concepts. There were 13 questioners obtained from 13 respondents.

Later on, 8 respondents were interviewed to gain more detailed information. In total, there are 8 interviewees with the respondents and one with non-respondent. A semi-structured interview method is used and most interviews were taken place in the office of the interviewees. There were 9 interviews were managed and the 
total duration is approximately 4 hours.

The questionnaires were distributed to key officers of 7 working unit/ departments (or Satuan Kerja Perangkat Daerah/SKPD) out of 31 departments in total within the city of Sabang. In total, there are 9 respondents/ interviewees in this study. They are head of the departments (SKPD), the secretary, head of program and reporting division of each working unit/SKPD.

In addition, secondary data is also collected for document analysis. The collected documents are LAKIP documents. The period of data collection is between January and February 2017.

The data analysis method used in this study was the content analysis that is a technique which validates the data by analyzing the context (Bungin, 2007:163). To examine the credibility of data or confidence in data of research result, triangulation technique, that is a technique to check the validity of data which uses something from outside the data for checking purposes or as a comparison against the data, was conducted (Moleong, 2007).

\section{ANALYSIS AND DISCUSSION \\ The Senior Officials' Understanding on PMS}

In this study, there are 23 questions are used to measure the understanding of the key officers on PMS concepts. Each question is marked with 0 , if the answer is false, and 1 , if the answer is correct. The lowest possible total score to be obtained by a respondent was 0 and the highest was 23 . The results shows that all senior officials of the seven departments/SKPD have a

Table 1.

Understanding PMS scores

\begin{tabular}{cccc}
\hline No. & $\begin{array}{c}\text { Range of } \\
\text { Value }\end{array}$ & Category & $\begin{array}{c}\text { Num- } \\
\text { ber of } \\
\text { SKPD }\end{array}$ \\
\hline 1. & $0-7$ & $\begin{array}{c}\text { Do Not Un- } \\
\text { derstand }\end{array}$ & - \\
2. & $8-15$ & $\begin{array}{c}\text { Less Under- } \\
\text { stand }\end{array}$ & - \\
3. & $16-23$ & Understand & 7 \\
\hline
\end{tabular}

Source: Result of Questionnaire (processed), 2017 good understanding on PMS concept and purposes.

The results of the study show that the key officers in Sabang local government known the PMS concept in general. The PMS has been understood as a system that taken into account several things in its implementation i.e. performance planning, performance indicators, performance measurement, performance reporting, and evaluation. They do aware that outcomeoriented performance measurement and accurate data are inseparable. However, the officers do not understand how to use the PMS resulted information for decision making and the measurement result analysis.

This aduequate understanding on the PMS concept is obtained by themselves and there is not enough facilitations and supports from the local government to improve their understating on the PMS. Indeed, the officers have a strong motivation to complete the tasks related to the implementation of PMS even without prior training. They learned PMS differently, either through the internet media, reading material or from others officers who have beett understanding and knowledge.

\section{The Implementation of Measurement and Performance Evaluation in Sabang Local Government}

The new PMS in Sabang local government has been implemented partially. The questionnaire results show that the components that had not been implemented are the analysis of performance measurement results and performance evaluation of the

Table 2.

The Implementation of PMS in the

\begin{tabular}{|c|c|c|c|}
\hline $\begin{array}{l}\text { No } \\
\text {. }\end{array}$ & $\begin{array}{c}\text { Range of } \\
\text { Value }\end{array}$ & Category & $\begin{array}{l}\text { Num- } \\
\text { ber of }\end{array}$ \\
\hline 1. & $0-9$ & $\begin{array}{l}\text { Not yet } \\
\text { properly }\end{array}$ & - \\
\hline 2. & $10-18$ & $\begin{array}{l}\text { Start to } \\
\text { properly }\end{array}$ & \\
\hline 3. & $19-28$ & $\begin{array}{l}\text { Has been } \\
\text { properly }\end{array}$ & 7 \\
\hline
\end{tabular}


departments by the Sabang local government.

Based on the result of the interview, it is found that there is one additional feature which is not in place namely, the use of performance information in decision making. Hatry (1999) as cited in Nisio et al. (2014) argues that the best indication of a succesfull PMS development is the high level of performance information use in the organization decision making process. Yet, the use of performance information should be supported by the effectiveness of performance indicators, the data quality, the accuracy of data collected, appropriate data analysis and presentation of information (Hatry, 2008 as cited in Nisio et al., 2014).

This study, in general, found that PMS implementation in Sabang Local Government had included performance planning, performance indicators, performance measurement and performance reporting. Despite the components of performance indicators had been fulfilled, the performance indicators and performance measures implemented by Sabang local government can be classified as outputoriented, rather than outcome-oriented. The difficulty in determining proper and accurate performance indicators had been a constraint for the local government in implementing the new PMS. The performance indicators which were still outputoriented and had not been able to describe the effectiveness of an activity, the absence of analysis of measurement results and accurate data contribute to a partial implementation of PMS in the local government.

This result is consistent with the result of Akbar et al. (2012). They found that Indonesian local government basically implemented the performance measurements to meet regulatory requirements from the Central Government. The case of PMS adoption in Sabang can be seen as a symbolic or formality with no significant impact on performance management. The newly PMS is developed to fulfill the demand of the central government, rather than to improve the performance of the local government. Similar with Akbar et al. (2015), the motivation of PMS adoption in Sabang can be explained by using the institutional theory.
This study confirms that coercive isomorphism is the most likely explanation behind the implementation or the development of the PMS. Consequently, the results of PMS i.e. indicators and strategies are barely used in the daily operation.

\section{Supporting Factors and Obstacles of the PMS Implementation in Sabang Local Gov- ernment}

The implementation of PMS can be influenced by various factors. This study found that factors supported the implementation of PMS in Sabang local government are (1) the officers' motivation; and (2) the organizational commitment. Firstly, the staff motivation to improve their capacity in implementing PMS and their duty properly (selfefficacy) is one of the crucial supporting factors in the implementation of PMS in Sabang local government. This individual character can compensate the system shortcoming due to the lack of training regarding the implementation of PMS. Moreover, the existence of competent staff in the program and reporting division also become other supporting factor. Kennerley and Neely (2002) believe that the lack of technical ability and human resources can hinder the implementation of PMS. A good individual character, which is not always related with academic competency, is found by Sofyani and Akbar (2015) as a competency to overcome the lack of relevancy between the staff education background and their duties. Although the staffs do not have a related academic background, they are willing to learn new things in order to meet the program objectives.

Secondly, the organization commitment also plays a supporting role. The head of departments showed the commitment by facilitating data collection, providing equipment and funds for PMS implementation activities. Moreover, member of other organizations, particularly the technical division, showed their strong commitment through providing data required in the new PMS adoption. This finding is in line with research conducted by Keathley and Van Aken (2013) also Akbar et al. (2012) who found that organizational commitment is a crucial factor affecting the 
Why does the recently adopted performance measurement system in Indonesia local government not work well? (Fahlevi, Nuzulia, dan Basri)

implementation of PMS.

Furthermore, this study also highlights some obstacles i.e. (1) the absence of education and training related to the implementation of PMS for officials and staffs conducting the performance measurement of SKPD; (2) the lack of evaluation mechanism of working unit/SKPD performance; (3) the organizational culture that is difficult to accept changes to measure the performance towards outcome-oriented in the absence of pressure; and (4) the difficulty in determining measurable and clear performance indicators consistent with the target. Training as the vital component of PMS adoption has been commonly found in various studies to support the implementation of PMS (Akbar et al., 2012; Sofyani and Akbar 2015, Syachbrani \& Akbar, 2013, Keathly and Van Aken (2013); Nurkhamid (2008). However, the absence of training related to PMS development apparently hinder the full implementation of PMS and in fact delayed the implementation for 5 years.

Moreover, the absence of performance evaluation can also discourage the implementation of PMS. It was reported by the officials that the new PMS has not set up a clear reward and punishment for good perform and bad perform departments/ SKPDs. This finding is in line with the study of Jurnali and Nabiha (2015) that SAKIP is the applicable PMS in Indonesia which has been comprehensive in concept except for the absence of rewards and punishment.

Finally, the organizational culture which resists changes also makes it difficult for the new PMS implementation. This can be associated with the composition of the staff where most of them are not young anymore. Besides, there is not enough pressure to implement PMS in the local government. This finding is consistent with the findings of the study of Sihaloho and Halim (2005) and Syachbrani and Akbar (2013).

\section{CONCLUSION}

The adoption of performance management system in the governmental institution can be problematic. This study explores the understanding of key officers of an Indone- sian local government, Sabang city, on PMS (SAKIP and LAKIP) and how the departments used the PMS results. Based on collected questioners and interviews with 8 key informants this study uncovered sufficient knowledge and understanding of the key officers on the new introduced PMS. However, the officers have a lack of understanding on some crucial features of PMS, namely the use of PMS output's for decision making and improving the organizational performance.

Moreover, this study also demonstrates that the difficulties in formulating proper and precise performance indicators. Drawn from the institutional theory, the result of this study indicate that the local government adopts the newly PMS mainly to align with the central government instruction, rather than to improve its performance. This phenomena called coercive isomorphism and has been found also in several previous studies on PMS in public sector organization.

As this study adopt case study, the results cannot be generalized to other local governments in Indonesia. This study provides a complex understanding on PMS adoption and it can be used for improving the performance management system and the understanding of key officers. Another limitation is the number of involved departments/SKPDs. In this study, there were 7 out of 31 departments were involved.

For further studies, researchers can use other theory, for example organizational learning theory to gain a different point of view. It is also suggested to conduct the research to explore and examine the determinants of succesful PMS adoption in local governments.

Lastly, the results of this study can be used by Sabang local government to improve the quality and benefit of the new PMS. The key officers need proper training on how to use the indicators resulted from the LAKIP to increase the department performance. Above all, the most crucial element could be the organizational commitment on developing and using PMS and its indicators in achieving the local government goals and targets. 


\section{REFERENCES}

Ahyaruddin, M., \& Akbar, R. (2018). Indonesian Local Government's Accountability and Performance: the Isomorphism Institutional Perspective. Jurnal Akuntansi Dan Investasi, 19(1), 1-11. https://doi.org/10.18196/jai.190187

Akbar, R., Pilcher, R. A., \& Perrin, B. (2015). Implementing performance measurement systems: Indonesian local government under pressure. Qualitative Research in Accounting \& Management, 12(1), 3-33.

Akbar, R., Pilcher, R., Perrin, B., (2012). Performance measurement in Indonesia: the case of local government. Pacific Accounting Review, 24(3), 262-291. https://doi.org/10.1108/01140581211 283878

Arnaboldi, M., \& Azzone, G. (2010). Constructing performance measurement in the public sector. Critical Perspectives on Accounting, 21(4), 266-282. https://doi.org/10.1016j.cpa.2010. 01.016

Arnaboldi, M., Lapsley, I., \& Steccolini, I. (2015). Performance management in the public sector: The ultimate challenge. International Journal of Public Sector Management, 31(1), 1-22. https://doi.org/10.1111/faam.12049

Ashworth, R., Boyne, G., \& Delbridge, R. (2009). Escape from the iron cage? Organizational change and isomorphic pressures in the public sector. Journal of Public Administration Research and Theory, 19(1), 165-187. https:// doi.org/10.1093/jopart/mum038

Atkinson, A. A. and McCrindell, J. Q., 1997. Strategic performance measurement in government, CMA Magazine, April, 20 $-23$

Brignall, S., \& Modell, S. (2000). An institutional perspective on performance measurement and management in the "new public sector." Management Accounting Research, 11(3), 281-306. h t t p s: / / d o i.org / $10.1006 /$ mare.2000.0136

Bungin, B., (2007). Penelitian Kualitatif: Komunikasi, Ekonomi, Kebijakan Publik dan Ilmu Sosial lainnya Jakarta: Putra Grafika
DiMaggio, P. J., \& Powell, W. W. (1983). The Iron Cage Revisited: Institutional Isomorphism and Collective Rationality in Organizational Fields. American Sociological Review, 48(2), 147-160. https:// doi.org/Article

Fahlevi, H. (2016). Understanding why the role of accounting is unchanged in Indonesian public hospitals. Journal of Accounting and Organizational Change, 12(2), 203-222 https:// doi.org/10.1108/JAOC-03-2014-0020

Fahlevi, H., Muhardiansyah, \& Aliamin. (2018). Does Increasing Central Government Transfer Improve Local Government Performance? A Case of Aceh Provincial Government. Presented in The First Padang International Conference On Economics Education, Economics, Business and Management, Accounting and Entrepreneurship (PICEEBA 2018), 21-26.

Fryer, K., Antony, J., \& Ogden, S. (2009). Performance management in the public sector. International Journal of Public Sector Management, 22(6), 478-498. https://doi.org/10.1108/09513550910 982850

Greiling, D. (2006). Performance measurement : a remedy for increasing the efficiency of public services? International Journal of Productivity and Performance Management, 55(6), 448-456. https://doi.org/10.1108/1741040061

0682488

Jansen, E. P. (2008). New public management: perspectives on performance and the use of performance information. Financial Accountability \& Management, 24 (2), 169-191.

Jurnali, T., \& Siti-Nabiha, A. K. (2015). Performance Management System for Local Government: The Indonesian Experience. Global Business Review, 16(3), 351-363. https://doi.org/10.1177/09 72150915569923

Kennerley, Mike \& Neely, Andi (2002). A Framework of The Factors Affecting The Evolution of Performance Measurement System. International Journal of Operatian and Operation Management. Vol 22 (11), p. 1222-1245

Keathley, H., \& Van Aken, E. (2013). System- 
atic literature review on the factors that affect performance measurement system implementation. Presented at the Industrial and Systems Engineering Research Conference, 18-22 May, San Juan, Puerto Rico.

Kuhlmann, S. (2010). Performance Measurement in European local governments: a comparative analysis of reform experiences in Great Britain, France, Sweden and Germany. International Review of Administrative Sciences, 76(2), 331345. https://doi.org/10.1177/002085 2310

Moleong, L. (2007). Metodologi Penelitian Kualitatif. Bandung: Remaja Karya.

Moynihan, D. (2006). What Can Baseball Teach Us about Performance Management? Public Administration Review, 66(4), 647-648. https://doi.org/10.11 11/j.1540-6210.2006.00626.x

Nisio, A.; Losurdo, S. \& De Carolis, R. (2014). Use of performance information in Italian municipalities: some empirical evidences. Revista Administratie si Management Public (RAMP). 22(1), 6-25.

Nurkhamid, M. 2008. Implementasi Inovasi Sistem Pengukuran Kinerja Instansi Pemerintah, Vol. 3 (1). Jurnal Akuntansi Pemerintah. 45-75

Rantanen, H., Kulmala, H. I., Lönnqvist, A., \& Kujansivu, P. (2007). Performance measurement systems in the Finnish public sector. International Journal of Public Sector Management, 20(5), 415433. https://doi.org/10.1108/0951355 0710772521

Sihaloho, FL \& Halim, A. (2005). Pengaruh Faktor-Faktor Rasional, Politik dan Kultur Organisasi Terhadap Pemanfaatan Informasi Kinerja Instansi Pemerintah Daerah. Presented in Simposium Nasional Akuntansi VIII Solo, 15- 16 September, p. 774-790.

Syachbrani, W., \& Akbar, R. (2013). FaktorFaktor Teknis dan Keorganisasian yang Memengaruhi Pengembangan Sistem Pengukuran Kinerja Pemerintah Daerah. Jurnal Reviu Akuntansi Dan Keuangan, 3(2), 447-464.

Verbeeten, F. H. . (2008). Performance management practices in public sector organizations. Accounting, Auditing \& Accountability Journal, 21(3), 427-454. https://doi.org/10.1108/09513570810 863996

Sofyani, H., \& Akbar, R. (2013). Hubungan faktor internal institusi dan implementasi sistem akuntabilitas kinerja instansi pemerintah (sakip) di pemerintah daerah. Jurnal Akuntansi dan Keuangan Indonesia, 10(2), 184205. http://dx.doi.org/10.21002/ jaki.2013.10 